\title{
Duration of Dual Antiplatelet Therapy After Implantation of Drug-Coated Balloon
}

\author{
Yuxuan Zhang ${ }^{1 \dagger}$, Xinyi Zhang ${ }^{1 \dagger}$, Qichao Dong ${ }^{1}$, Delong Chen ${ }^{1}, Y_{i} X_{u^{2}}$ and Jun Jiang ${ }^{1 *}$ \\ ${ }^{1}$ Department of Cardiology, Second Affiliated Hospital, School of Medicine, Zhejiang University, Hangzhou, China, \\ ${ }^{2}$ Department of Cardiology, Ningbo First Hospital, Ningbo, China
}

OPEN ACCESS

Edited by:

Gianluca Caiazzo,

Azienda Sanitaria Locale Caserta, Italy

Reviewed by:

Arturo Cesaro

University of Campania Luigi

Vanvitelli, Italy

Enrico Fabris,

University of Trieste, Italy

*Correspondence:

Jun Jiang

jiang-jun@zju.edu.cn

${ }^{\dagger}$ These authors have contributed equally to this work and share first authorship

Specialty section:

This article was submitted to

Coronary Artery Disease,

a section of the journal

Frontiers in Cardiovascular Medicine

Received: 21 August 2021 Accepted: 08 November 2021 Published: 01 December 2021

Citation:

Zhang Y, Zhang $X$, Dong $Q$, Chen D, $X u Y$ and Jiang J (2021) Duration of Dual Antiplatelet Therapy After Implantation of Drug-Coated Balloon. Front. Cardiovasc. Med. 8:762391. doi: 10.3389/fcvm.2021.762391
The drug-coated balloon (DCB) is an emerging percutaneous coronary intervention ( $\mathrm{PCl}$ ) device with theoretical advantages and promising results. Recent clinical observations have demonstrated that DCB tends to have both good efficacy and a good safety profile in the treatment of in-stent restenosis (ISR) for both bare-metal and drug-eluting stents (DES), de novo coronary artery disease (CAD), and other situation, such as high bleeding risk, chronic total occlusion, and acute coronary syndrome (ACS). Dual antiplatelet therapy (DAPT) has become an essential medication in daily clinical practice, but the optimal duration of DAPT after the implantation of a DCB remains unknown. At the time of the first in vivo implantation of paclitaxel-DCB for the treatment of ISR in 2006, the protocol-defined DAPT duration was only 1 month. Subsequently, DAPT duration ranging from 1 to 12 months has been recommended by various trials. However, there have been no randomized controlled trials (RCTs) on the optimal duration of DAPT after DCB angioplasty. Current clinical guidelines normally recommend the duration of DAPT after DCB-only angioplasty based on data from RCTs on the optimal duration of DAPT after stenting. In this review, we summarized current clinical trials on DCB-only angioplasty for different types of CADs and their stipulated durations of DAPT, and compared their clinical results such as restenosis, target lesion revascularization (TLR) and stent thrombosis event. We hope this review can assist clinicians in making reasonable decisions about the duration of DAPT after DCB implantation.

\footnotetext{
Keywords: drug-coated balloon, dual antiplatelet therapy, in-stent restenosis, de novo coronary artery disease, percutaneous coronary intervention
}

\section{INTRODUCTION}

Drug-coated balloon (DCB) technology is a combined therapy that involves a balloon and drug to treat coronary lesions, eliminating stent thrombosis, and reducing the rate of restenosis by leaving no metal behind (1). Since 2001, the DCB has been tested experimentally (1), and was later clinically validated in small-randomized controlled trials (RCTs) on coronary in-stent restenosis (ISR) (2) and peripheral stenosis (3). This technology has played an increasingly important role in the field of percutaneous coronary intervention (PCI), and a variety of products have been developed (Table 1). Drug-coated balloon technology has demonstrated safety and efficacy in the treatment of ISR and is recommended by guidelines as Class 1 indication for the treatment of ISR (5-8). Meanwhile, an increasing number of clinical studies using DCB have shown promising results for the treatment of both small and large vessel de novo coronary artery disease (CAD), bifurcation lesions, and other variable disease subsets. 
TABLE 1 | Major current drug-coated balloon available in the market (4).

\begin{tabular}{|c|c|c|c|c|c|}
\hline Name & Manufacturer & Type & Dosage & Coating method & Release characteristics \\
\hline SeQuent please & $\begin{array}{l}\text { B. Braun Melsungen AG, } \\
\text { Berlin, Germany }\end{array}$ & Paclitaxel & $3 \mu \mathrm{g} / \mathrm{mm}^{2}$ & $\begin{array}{l}\text { Matrix coating: paclitaxel + } \\
\text { hydrophilic spacer (iopromide) }\end{array}$ & $\begin{array}{l}\text { Inflate for at least } 40 \text { s to allow enough } \\
\text { drug to be released into the vessel wall } \\
\text { ( } 4.5 \% \text { of the drug remains on the balloon) }\end{array}$ \\
\hline DIOR-II & $\begin{array}{l}\text { Eurocor GmbH, Bonn, } \\
\text { Germany }\end{array}$ & Paclitaxel & $3 \mu \mathrm{g} / \mathrm{mm}^{2}$ & $\begin{array}{l}\text { 1:1 mixture of aleuritic and } \\
\text { shellolic acid with paclitaxel } \\
\text { (shellac } ® \text { coating) }\end{array}$ & $\begin{array}{l}\text { Drug delivery by simple diffusion, inflate } \\
20-30 \text { s at normal pressure }\end{array}$ \\
\hline Elutax & $\begin{array}{l}\text { Aachen Resonance GmbH, } \\
\text { Aachen, Germany }\end{array}$ & Paclitaxel & $2 \mu \mathrm{g} / \mathrm{mm}^{2}$ & $\begin{array}{l}\text { Two layers of paclitaxel (the first } \\
\text { on the inflated balloon and the } \\
\text { second as a crystal power), } \\
\text { without any excipient }\end{array}$ & $\begin{array}{l}10 \% \text { of the drug remains on the balloon } \\
\text { after an inflation of 30-60 s }\end{array}$ \\
\hline RESTORE DCB & $\begin{array}{l}\text { Cardionovum, Bonn, } \\
\text { Germany }\end{array}$ & Paclitaxel & $3 \mu \mathrm{g} / \mathrm{mm}^{2}$ & Shellac & $\begin{array}{l}\text { A short-term balloon-to-vessel wall } \\
\text { contact time of } 45 \mathrm{~s} \text { is enough }\end{array}$ \\
\hline Pantera Lux & $\begin{array}{l}\text { Biotronik, Bulach, } \\
\text { Switzerland }\end{array}$ & Paclitaxel & $3 \mu \mathrm{g} / \mathrm{mm}^{2}$ & $\begin{array}{l}\text { Paclitaxel + butyryl-trihexyl } \\
\text { citrate }\end{array}$ & $\begin{array}{l}\text { Minimum inflation time is } 30 \mathrm{~s} \text { to allow } \\
\text { enough drug to be released into the vessel } \\
\text { wall }\end{array}$ \\
\hline Danubio & $\begin{array}{l}\text { Minvasys, Gennevilliers, } \\
\text { France }\end{array}$ & Paclitaxel & $2.5 \mu \mathrm{g} / \mathrm{mm}^{2}$ & $\begin{array}{l}\text { Paclitaxel + butyryl-trihexyl } \\
\text { citrate }\end{array}$ & $\begin{array}{l}\text { Minimum inflation time is } 30 \mathrm{~s} \text { to allow } \\
\text { enough drug to be released into the vessel } \\
\text { wall }\end{array}$ \\
\hline Protégé and Protégé NC & $\begin{array}{l}\text { Blue Medical, Helmond, } \\
\text { Netherlands }\end{array}$ & Paclitaxel & $3 \mu \mathrm{g} / \mathrm{mm}^{2}$ & $\begin{array}{l}\text { Drug component encapsulated } \\
\text { in wings using Wing Seal } \\
\text { Technology }\end{array}$ & $\begin{array}{l}\text { Load secured to achieve the therapeutic } \\
\text { window within } 30 \mathrm{~s} \text { inflation time, also } \\
\text { available with non-compliant balloon }\end{array}$ \\
\hline MagicTouch & $\begin{array}{l}\text { Concept Medical, Surat, } \\
\text { India }\end{array}$ & Sirolimus & $1.27 \mu \mathrm{g} / \mathrm{mm}^{2}$ & $\begin{array}{l}\text { Sirolimus is encapsulated in a } \\
\text { phospholipid bi-layer as drug } \\
\text { carrier and in Nanocarriers } \\
\text { configuration }\end{array}$ & Inflate for at least $45 \mathrm{~s}$ if clinically tolerated \\
\hline IN.PACT Falcon & $\begin{array}{l}\text { Medtronic, Inc., Santa } \\
\text { Rosa, California, USA }\end{array}$ & Paclitaxel & $3 \mu \mathrm{g} / \mathrm{mm}^{2}$ & $\begin{array}{l}\text { Crystalline coating: paclitaxel + } \\
\text { urea (FreePac } ® \text { ) }\end{array}$ & $\begin{array}{l}\text { Inflate } 30-60 \text { s at normal pressure to allow } \\
\text { enough drug release into the vessel wall } \\
\text { ( } 4.7 \% \text { of the drug remains on the balloon) }\end{array}$ \\
\hline Agent & $\begin{array}{l}\text { Boston Scientific, Natick, } \\
\text { MA, USA }\end{array}$ & Paclitaxel & $2 \mu \mathrm{g} / \mathrm{mm}^{2}$ & $\begin{array}{l}\text { Balanced hydrophobic and } \\
\text { hydrophilic properties of } \\
\text { TransPax, Fewer particulates are } \\
\text { lost distally during the procedure }\end{array}$ & $\begin{array}{l}\text { Inflate for at least } 30 \mathrm{~s} \text { to allow enough } \\
\text { drug to be released into the vessel wall }\end{array}$ \\
\hline AngiosculptX & $\begin{array}{l}\text { Spectranetics, Colorado } \\
\text { Springs, Colorado, USA }\end{array}$ & Paclitaxel & $3 \mu \mathrm{g} / \mathrm{mm}^{2}$ & $\begin{array}{l}\text { Nordihydroguaiaretic acid } \\
\text { excipient to facilitate drug } \\
\text { transfer to tissue }\end{array}$ & $\begin{array}{l}\text { Inflate for at least } 30 \mathrm{~s} \text {, Improved dilatation } \\
\text { in calcified or resistant lesion using a } \\
\text { scoring balloon }\end{array}$ \\
\hline Chocolate touch & QT Vascular & Paclitaxel & $3 \mu \mathrm{g} / \mathrm{mm}^{2}$ & $\begin{array}{l}\text { Crystalline paclitaxel coating with } \\
\text { hydrophilic excipient }\end{array}$ & $\begin{array}{l}\text { The pillows and grooves of the inflated } \\
\text { Chocolate Touch balloon result in } 20 \% \\
\text { more drug-coated surface compared to } \\
\text { conventional balloons of the same size }\end{array}$ \\
\hline Essential & Ivascular & Paclitaxel & $3 \mu \mathrm{g} / \mathrm{mm}^{2}$ & Microcrystalline coating & $\begin{array}{l}\text { Inflation process must last from } 30 \text { s to } 1 \\
\text { min }\end{array}$ \\
\hline
\end{tabular}

Dual antiplatelet therapy (DAPT) has become an essential medication in daily clinical practice; it combines aspirin and a $\mathrm{P}_{2} \mathrm{Y}_{12}$-receptor inhibitor following PCI and is needed for the primary prevention of stent thrombosis and the secondary prevention of ischemic thrombotic event. With the "leave nothing behind" strategy, based on the shorter period of inflammatory response without a metallic scaffold, this strategy offers the theoretical advantage of virtually eliminating the threat of thrombosis over both the short and long term. Therefore, one possible benefit for many patients using DCB-only angioplasty is a short duration of DAPT, in some cases only 4 weeks, such as in patients with a high bleeding risk (9).

However, it must be pointed out that all previous studies have not adequately addressed questions about the optimal duration of DAPT after DCB implantation. The purpose of this review is to outline different DAPT strategies and trials with the use of DCB for ISR, de novo lesions, and other specific situations and to explore the appropriate DAPT duration to assist clinical practice.

\section{CURRENT GUIDANCE}

As first recommended by the German Consensus Group (10), DAPT is necessary for 4 weeks if the DCB is used as a standalone procedure, and 6-12 months of DAPT is recommended in combination with bare metal stent (BMS). Then, they formulated more detailed recommendations regarding DAPT duration. In cases of the treatment of an ISR, the patient should receive 
aspirin $100 \mathrm{mg}$ in the long-term and additional clopidogrel $75 \mathrm{mg}$ for 4 weeks after PCI in BMS and at least 4 weeks or the duration defined by the drug-eluting stent (DES) implantation date. After treatment of small vessel de novo coronary lesions, aspirin $100 \mathrm{mg}$ should be given long-term and clopidogrel $75 \mathrm{mg}$ is recommended for 4 weeks after PCI with DCB alone and for 3 months after DCB with additional spot BMS. Dual antiplatelet therapy is recommended for 4 weeks if only DCB without stenting is used for the treatment of a bifurcation lesion and 6-12 months in case stents are used before or after the DCB procedure. To treat acute coronary syndromes (ACS), the recommended duration of DAPT is 12 months regardless of the use of a BMS, DES, or DCB (11). The Italian Position Group gave similar recommendations regarding a DAPT duration of at least 1 month in the case of DCB-only treatment and 3 months in cases of the implantation of a BMS (12).

However, the European Society of Cardiology Guidelines on DAPT gave more conservative recommendations. In patients with stable CAD treated with DCB, DAPT for 6 months should be considered. Dual antiplatelet therapy for 3 months should be considered if patients with stable CAD are considered a high bleeding risk. In patients with stable CAD in whom 3-months DAPT poses safety concerns, DAPT for 1 month may be considered. As in patients with ACS treated with coronary stent implantation, DAPT with a $\mathrm{P}_{2} \mathrm{Y}_{12}$ inhibitor on top of aspirin is recommended for 12 months unless contraindicated. In cases of patients who are at high risk of bleeding, discontinuation of $\mathrm{P}_{2} \mathrm{Y}_{12}$ inhibitor therapy after 6 months should be considered (13).

Recently, the Asia-Pacific Consensus Group updated the DCB treatment protocols for $\mathrm{CAD}$ and gave their recommendations regarding optimal medical treatment. For the treatment of BMSISR and DES-ISR, patients should maintain a lifelong therapy with aspirin $100 \mathrm{mg}$ and take clopidogrel $75 \mathrm{mg}$ for at least 13 months. For the treatment of de novo coronary disease except ACS with DCB only, patients should receive DAPT for at least 1 month and then receive aspirin $100 \mathrm{mg}$ for life. Moreover, in cases of de novo stable coronary disease with DCB plus bail-out BMS, DAPT is recommended for at least 3-6 months. For the treatment of bifurcation disease, if the DCB-only method without stenting is used, the duration of DAPT should be the same as other de novo coronary disease. In the case of the DCB method plus stenting, the recommended DAPT duration is at least 6-12 months. For patients with ACS, similar to other guidelines, DAPT is recommended for at least 12 months regardless of the use of BMS, DCB, or DES (7).

\section{PHARMACOLOGY OF ANTIPLATELETS}

The goal of antiplatelet therapy after PCI is to maximize protection against short- and long-term postoperative stent or vessel thrombosis by blocking platelet activation while limiting bleeding risk. Figure 1 illustrates the main mechanisms of platelet activation and the sites of action of antiplatelet agents. Platelet adhesion is mediated by the interaction between platelet receptors and ligands exposed at the sites of vascular injury, e.g., the glycoprotein (GP) Ib/V/IX receptor complex with the von Willebrand factor and GPVI and GPla proteins with collagen (15-17). Then the local platelet activating factors, such as adenosine diphosphate (ADP), thromboxane $\mathrm{A}_{2}\left(\mathrm{TXA}_{2}\right)$, serotonin, and thrombin, promote and amplify the platelet activation by interacting with specific platelet membrane receptors [such as $\mathrm{P} 2 \mathrm{Y}$ purinoceptor 12 $\left(\mathrm{P}_{2} \mathrm{Y}_{12}\right)$, 5-hydroxytryptamine $2 \mathrm{~A}$ receptor, $\mathrm{TXA}_{2}$ receptor isoform- $\alpha$, and proteinase-activated receptors (PARs)] (15-17). Antiplatelet drugs block platelet activation through different phases: (1) Acetylsalicylic acid, commonly known as aspirin, is an irreversible cyclooxygenase 1 (COX1) inhibitor that diminishes platelet activation and aggregation promoted by $\mathrm{TXA}_{2}$ by blocking $\mathrm{TXA}_{2}$ production during pathological thrombus formation: (2) $\mathrm{P}_{2} \mathrm{Y}_{12}$ ADP receptor antagonists, which include clopidogrel, prasugrel, and ticagrelor, exert their clinical benefit by inhibiting the activation of $\mathrm{P}_{2} \mathrm{Y}_{12}$-mediated platelet activation during pathological thrombosis (when the occlusive plateletrich thrombus is formed); (3) Glycoprotein IIb/IIIa inhibitors, including eptifibatide and tirofiban, are currently only for ACS patients undergoing PCI, and interfere with platelet cross-linking and clot formation by competing with fibrinogen and vWF for GP IIb/IIIa binding; (4) Vorapaxar, as a PAR-1 inhibitor, blocks the binding of thrombin to PAR-1, thus inhibiting thrombininduced activation, and the aggregation of platelets; (5) Cilostazol is an inhibitor of phosphodiesterase type III, which possesses both antiplatelet and vasodilatory effects (15-17).

\section{DAPT DURATION IN MULTIPLE DISEASES}

\section{In-stent Restenosis}

In-stent restenosis remains the primary cause of PCI failure, though the development of DESs generations has improved anti-restenosis performance (18). A recent report showed that approximately $20 \%$ of patients required target lesion revascularization (TLR) at the 10-year follow-up (19). Several therapies for ISR of BMS or DES have been tested in clinical trials (20), and DCB and repeated stenting with DES have become the most effective therapeutic options, which have been recommended as class IA by guidance (5). A recent meta-analysis of 10 RCTs showed that DCB and DES were similarly effective and safe in the treatment of BMS-ISR, whereas DES had higher efficacy than DCB in the treatment of DES-ISR (21).

As the first trial demonstrated that paclitaxel-DCB angioplasty was superior to plain old balloon angioplasty (POBA) alone in BMS-ISR, the PACCOCATH ISR trial recommended DAPT for 1 month followed by treatment with aspirin alone (2). At 6 months, the primary endpoint late lumen loss (LLL) in-segment was lower in the DCB group than in the POBA group $(0.03 \pm 0.48 \mathrm{~mm}$ vs. $0.74 \pm 0.86 \mathrm{~mm}, P=0.002)$. Restenosis occurred in 10 of 23 patients $(43 \%)$ in the POBA group, compared to only 1 of 22 patients $(5 \%)$ in the DCB group $(P=0.002)$. Patents who required TLR were significantly fewer in the DCB group than in the POBA group ( 0 vs. $6 \%, P=0.02$ ). At 5 years, TLR rates were still significantly lower in the DCB group than in the POBA group (38.9 vs. $9.3 \%, P=0.004)$ (22). No stent thrombosis was found 


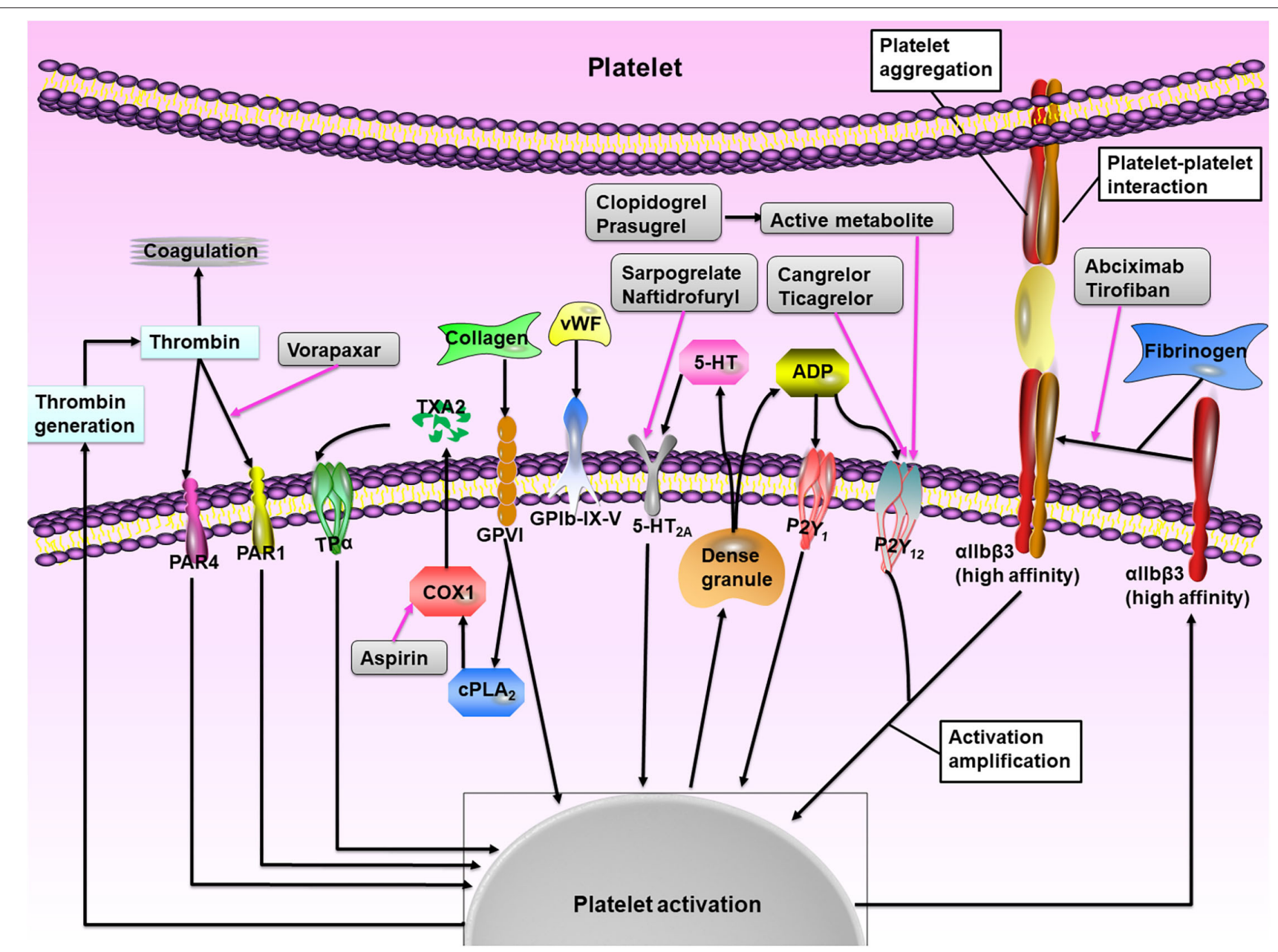

FIGURE 1 | The role of platelet activation. At the site of vascular injury, platelet adherence to the endothelium through the combination of glycoprotein (GP) receptors with exposed extracellular matrix proteins (particularly collagen and von Willebrand factor, vWF). Platelet activation occurs through complex intracellular signaling processes and leads to the release of various agonists, including thromboxane $A_{2}\left(T X A_{2}\right), A D P$, and 5-hydroxytryptamine (5-HT), which act by binding to their respective G protein-coupled receptors and mediate paracrine and autocrine platelet activation. The receptor P2Y purinoceptor 12 (P2Y 12 ) has a major role in the amplification of platelet activation, which is also supported by outside-in signaling via allbß33 integrin (the glycoprotein IIb/Illa receptor). The main platelet integrin GPIIb/Illa mediates platelet aggregation through conformational shape changes and binding to fibrinogen and vWF, thereby mediating the final common step of platelet activation. The net result of these interactions is thrombus formation mediated by the interaction of platelet aggregate with fibrin and thrombin. The available drugs (gray boxes) blockade different pathways of platelet activation and show additive inhibitory effects when used in combination. PAR, proteinase-activated receptor; TP $\alpha, \mathrm{TXA}_{2}$ receptor isoform- $\alpha$; COX1, cyclooxygenase 1. Adapted from Varga-Szabo et al. (14).

during the entire follower-up trial, which suggests that shortterm DAPT may be feasible and safe for patients who undergo DCB angioplasty.

In most trials on BMS-ISR treatment, DAPT with aspirin $100 \mathrm{mg}$ per day and clopidogrel was recommended for 3 months (23-26) (Table 2). Among these trials, only two cases of stent thrombosis were found during the follow-up $(24,25)$. It is worth mentioning that one patient in the DCB group experienced stent thrombosis due to clopidogrel discontinuation before late angiography in the RIBS V trial. The PEPCAD II ISR study showed that 19 of 66 (28.8\%) patients in the DCB group and 42 of $65(64.4 \%)$ patients in the DES group were still using clopidogrel $(P<0.0001)$ at 6 months, whereas after 12 months, the usage declined to 12 of $66(18.1 \%)$ and 27 of $65(41.5 \%)$, respective $(P<$
0.01) (23). However, there was no significance difference between the treatment groups with DAPT at 1 and 3 years $(P=0.80$ and 0.47 , respectively) (35).

However, the duration of DAPT varied from 3 to 12 months in trials for DES-ISR treatment (Table 2). In the RIBS IV randomized clinical trial, which showed DCB had lower efficacy compared to EES in patients presenting with DES-ISR, DAPT was prescribed for only 3 months after DCB angioplasty, and then aspirin monotherapy was maintained $(30,36)$. The TLR rates were significantly reduced in the EES group both at 1-year ( 4.5 vs. $13.0 \%, P=0.007$ ) and 3 -years $(7.1$ vs. $15.6 \%, P=0.015$ ) follow-up, but the need for "late" ( $>1$ year) TLR ( 2.6 vs. $4 \%$ ) was similar in the two groups. Stent thrombosis (both definitive and probable) occurred in three patients (two in the DCB group and 
TABLE 2 | Characteristics of randomized trials of DCB for treatment of ISR.

\begin{tabular}{|c|c|c|c|c|c|c|c|}
\hline Trial (year) & $\begin{array}{l}\text { Patients, } \\
\text { N }\end{array}$ & Design & $\begin{array}{l}\text { DAPT } \\
\text { duration } \\
\text { (months) }\end{array}$ & $\begin{array}{l}\text { Primary endpoint } \\
\text { (follow-up, months) }\end{array}$ & $\begin{array}{l}\text { Binary } \\
\text { restenosis } \\
\text { rate, } \%\end{array}$ & $\begin{array}{l}\text { TLR, \% (follow-up, } \\
\text { months) }\end{array}$ & $\begin{array}{l}\text { ST, } N \\
\text { (follow-up, } \\
\text { months) }\end{array}$ \\
\hline \multicolumn{8}{|l|}{ BMS-ISR } \\
\hline $\begin{array}{l}\text { PACCOCATH ISR } \\
(2006)(2)\end{array}$ & 52 & $\begin{array}{l}\text { DCB vs. } \\
\text { POBA }\end{array}$ & $\begin{array}{l}1 \text { in both } \\
\text { groups }\end{array}$ & $\begin{array}{l}\text { LLL: } 0.03 \pm 0.48 \mathrm{~mm} \text { vs. } \\
0.74 \pm 0.86 \mathrm{~mm}^{\star}(6)\end{array}$ & 5 vs. $43 \%{ }^{*}$ & 0 vs. $23 \%^{\star \star}(12)$ & 0 vs. 0 (12) \\
\hline $\begin{array}{l}\text { PEPCAD II isr } \\
(2009)(23)\end{array}$ & 131 & DCB vs. PES & $\begin{array}{l}3 \text { in DCB vs. } \\
6 \text { in PES }\end{array}$ & $\begin{array}{l}\text { LLL: } 0.17 \pm 0.42 \mathrm{~mm} \text { vs. } \\
0.38 \pm 0.61 \mathrm{~mm}(6)\end{array}$ & 7 vs. $20 \%$ & 6.3 vs. $15.4 \%(36)$ & 0 vs. $0(36)$ \\
\hline ribs V (2014) (24) & 189 & DCB vs. EES & $\begin{array}{l}3 \text { in DCB vs. } \\
12 \text { in EES }\end{array}$ & $\begin{array}{l}\text { MLD: } 2.01 \pm 0.6 \mathrm{~mm} \text { vs. } \\
2.36 \pm 0.6 \mathrm{~mm}^{\star}(9)\end{array}$ & 9.5 vs. $4.7 \%$ & $\begin{array}{l}6 \text { vs. } 1 \%(12) \\
8 \text { vs. } 2 \%{ }^{\star \star}(36)\end{array}$ & 1 vs. $0(36)$ \\
\hline $\begin{array}{l}\text { PATENE-C (2016) } \\
(25)\end{array}$ & 61 & $\begin{array}{l}\text { PCSB vs. } \\
\text { USB }\end{array}$ & 3 in both & $\begin{array}{l}\text { LLL: } 0.17 \pm 0.40 \mathrm{~mm} \text { vs. } \\
0.48 \pm 0.51 \mathrm{~mm}^{\star}(6)\end{array}$ & 7 vs. $41 \%{ }^{*}$ & 3 vs. $32 \%{ }^{*}(12)$ & 0 vs. 0 (12) \\
\hline $\begin{array}{l}\text { Pleva et al. (2016) } \\
\text { (26) }\end{array}$ & 136 & DCB vs. EES & $\begin{array}{l}3 \text { in DCB vs. } \\
6-12 \text { in EES }\end{array}$ & $\begin{array}{l}\text { LLL: } 0.09 \pm 0.73 \mathrm{~mm} \text { vs. } \\
0.44 \pm 0.73 \mathrm{~mm}^{\star}(12)\end{array}$ & $\begin{array}{l}8.7 \text { vs. } \\
19.12 \%\end{array}$ & 7.35 vs. $16.18 \%$ (12) & 1 VS. 0 (12) \\
\hline \multicolumn{8}{|l|}{ DES-ISR } \\
\hline $\begin{array}{l}\text { PEPCAD-DES } \\
(2012)(27)\end{array}$ & 110 & $\begin{array}{l}\text { DCB vs. } \\
\text { POBA }\end{array}$ & $\begin{array}{l}6 \text { in both } \\
\text { groups }\end{array}$ & $\begin{array}{l}\text { LLL: } 0.43 \pm 0.61 \mathrm{~mm} v \mathrm{~s} . \\
1.03 \pm 0.77 \mathrm{~mm}^{\star}(6)\end{array}$ & $\begin{array}{l}17.2 \mathrm{vs} . \\
58.1 \%{ }^{*}\end{array}$ & $\begin{array}{l}15.3 \text { vs. } 36.6 \%^{\star *}(6) \\
19.4 \text { vs. } 36.8 \%^{\star \star}(36)\end{array}$ & 1 vs. $4^{\star \star}(36)$ \\
\hline $\begin{array}{l}\text { ISAR-DESIRE } \\
\text { 3(2013) (28) }\end{array}$ & 402 & $\begin{array}{l}\text { DCB vs. PES } \\
\text { vs. POBA }\end{array}$ & 6 in all groups & $\begin{array}{l}\text { DS: } 38.0 \% \text { in DCB vs. } \\
37.4 \% \text { in PES vs. } 54.1 \% \text { in } \\
\text { POBA }(6-8)\end{array}$ & NA & $\begin{array}{l}22.1 \% \text { in DCB vs. } \\
13.5 \% \text { in PES vs. } \\
43.5 \% \text { in POBA (12) } \\
33.3 \% \text { in DCB vs. } \\
24.2 \% \text { in PES vs. } \\
50.8 \% \text { in POBA (36) }\end{array}$ & $\begin{array}{l}1 \text { vs. } 1 \text { vs. } 0 \\
(12) \\
1 \text { vs. } 2 \text { vs. } \\
0 \text { (36) }\end{array}$ \\
\hline $\begin{array}{l}\text { Pepcad China ISR } \\
\text { (2014) (29) }\end{array}$ & 220 & DCB vs. PES & $\begin{array}{l}12 \text { in both } \\
\text { groups }\end{array}$ & $\begin{array}{l}\text { LLL: } 0.46 \pm 0.51 \mathrm{~mm} \text { vs. } \\
0.55 \pm 0.61 \mathrm{~mm}(9)\end{array}$ & $\begin{array}{l}18.6 \mathrm{vs} . \\
23.8 \%\end{array}$ & $\begin{array}{l}15.6 \text { vs. } 12.3 \%(12) \\
15.9 \text { vs. } 13.7 \%(24)\end{array}$ & $\begin{array}{l}1 \text { vs. } 2(12) \\
1 \text { vs. } 3(24)\end{array}$ \\
\hline Ribs IV (2015) (30) & 309 & DCB vs. EES & $\begin{array}{l}3 \text { in DCB vs. } \\
12 \text { in EES }\end{array}$ & $\begin{array}{l}\text { MLD: } 1.80 \pm 0.6 \mathrm{~mm} \text { vs. } \\
2.03 \pm 0.7 \mathrm{~mm}^{\star}(6-9)\end{array}$ & 19 vs. $11 \%$ & $\begin{array}{l}13.0 \text { vs. } 4.5 \%^{*}(12) \\
15.6 \text { vs. } 7.1 \%^{* \star}(36)\end{array}$ & $\begin{array}{l}3 \text { vs. } 2(12) \\
4 \text { vs. } 2(36)\end{array}$ \\
\hline $\begin{array}{l}\text { ISAR-DESIRE } 4 \\
(2017)(31)\end{array}$ & 252 & $\begin{array}{l}\text { DCB vs. } \\
\text { SB-DCB }\end{array}$ & $\begin{array}{l}6 \text { in both } \\
\text { groups }\end{array}$ & $\begin{array}{l}\text { DS: } 40.4 \pm 21.4 \text { vs. } 35 \pm \\
16.8 \%^{* *}(6-8)\end{array}$ & $\begin{array}{l}32.0 \text { vs. } \\
18.5 \% \text { ** }\end{array}$ & 21.8 vs. $16.2 \%(12)$ & 0 vs. 0 (12) \\
\hline Restore (2018) (32) & 172 & DCB vs. EES & $\begin{array}{l}6 \text { in both } \\
\text { groups }\end{array}$ & $\begin{array}{l}\text { LLL: } 0.15 \pm 0.49 \mathrm{~mm} \text { vs. } \\
0.19 \pm 0.41 \mathrm{~mm}(9)\end{array}$ & 19.5 vs. $5.6 \%$ & 5.8 vs. $1.2 \%(12)$ & 0 vs. 0 (12) \\
\hline \multicolumn{8}{|c|}{ Both BMS-ISR and DES-ISR } \\
\hline DARE (2018) (33) & 278 & DCB vs. EES & $\begin{array}{l}12 \text { in both } \\
\text { groups }\end{array}$ & $\begin{array}{l}\text { MLD: } 1.71 \pm 0.51 \text { vs. } 1.74 \\
\pm 0.61 \text { (6) }\end{array}$ & $\begin{array}{l}18.1 \mathrm{vs} . \\
20.9 \%\end{array}$ & 8.8 vs. $7.1 \%(12)$ & 0 vs. 0 (12) \\
\hline Blolux (2018) (34) & 229 & DCB vs. SES & $\begin{array}{l}\text { Given as per } \\
\text { local standard }\end{array}$ & $\begin{array}{l}\text { LLL: } 0.03 \pm 0.40 \mathrm{~mm} \text { vs. } \\
0.20 \pm 0.70(6)\end{array}$ & NA & 13.5 vs. $11.6 \%(18)$ & 1 vs. 2 (18) \\
\hline
\end{tabular}

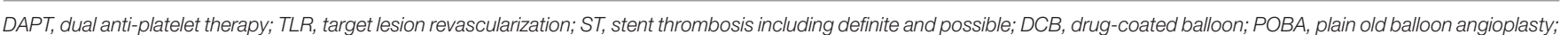

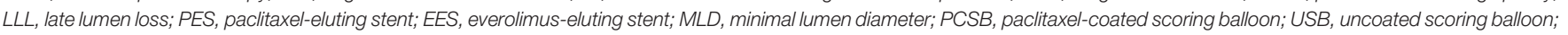
$D S$, diameter restenosis; SB-DCB, scoring balloon before drug-coated balloon; SES, sirolimus-eluting stent.

${ }^{\star} P<0.01$ vs. non-DCB group.

${ }^{\star *} P<0.05$ vs. non-DCB group.

one in the EES group) at 1 year and after that another two cases of stent thrombosis occurred in the DCB group at 3 years (36). However, during the actual follow-up for the trial, $84 \%$ of patients in the DCB group were still receiving DAPT at 9 months, and $64 \%$ were still receiving DAPT at 1 year, of which $52 \%$ suffered from unstable angina at the time of recruitment. For most trials, DAPT was administered for 6 months after DCB dilatation $(27,28,31,32)$. In these trials, DCB showed higher efficacy than POBA with DES-ISR treatment, which showed similar efficacy to DES. Two stent thrombosis cases were found in the DCB group during the follow-up, one in the PEPCAD-DES trial (37) and another in the ISAR-DESIRE trial (28). The PEPCAD China ISR trial also demonstrated that angioplasty with DCB was noninferior to PES implantation when used to treat DES-ISR $(29,38)$. In this trial, all patients, irrespective of treatment allocation, were prescribed DAPT for 12 months. There was one late stent thrombosis occurred in the DCB group and two in the PES group at the 1-year follow-up, and another very late stent thrombosis occurred in the PES group at the 2-year follow-up (38).

\section{Small Vessel de novo Coronary Artery Disease}

It remains challenging to treat coronary small-vessel disease, which is usually defined as lesions in vessels $<3.0$ or $\leq 2.75 \mathrm{~mm}$, because it is significantly and directly associated with an increased risk of clinical events (39). Though DES has been found to be equally effective in small and large vessels, the resulting LLL occupies a higher percentage of the respective vessel diameter, leading to a higher incidence of ISR and other clinical events (40). 
TABLE 3 | Characteristics of randomized control trials of DCB for treatment of small vessel de novo coronary artery disease.

\begin{tabular}{|c|c|c|c|c|c|c|c|}
\hline Trial (year) & $\begin{array}{l}\text { Patients, } \\
\qquad N\end{array}$ & Design & $\begin{array}{l}\text { DAPT duration } \\
\text { (months) }\end{array}$ & $\begin{array}{l}\text { Primary endpoint } \\
\text { (follow-up, months) }\end{array}$ & $\begin{array}{l}\text { Binary } \\
\text { restenosis } \\
\text { rate, } \%\end{array}$ & $\begin{array}{l}\text { TLR, \% (follow-up, } \\
\text { months) }\end{array}$ & $\begin{array}{l}\text { ST, N } \\
\text { (follow-up, } \\
\text { months) }\end{array}$ \\
\hline $\begin{array}{l}\text { PICCOLETO } \\
(2010)(42)\end{array}$ & 57 & DCB vs. DES & $\begin{array}{l}1 \text { in SAP and } \\
\text { alone DCB use vs. } \\
3 \text { in DCB + stent } \\
\text { implantation vs. } 12 \\
\text { in UAP or DES }\end{array}$ & DS: 43.6 vs. $24.3 \%{ }^{\star \star}(6)$ & $\begin{array}{l}32.1 \mathrm{vs} . \\
10.3 \%{ }^{* *}\end{array}$ & 32.1 vs. $10.3 \%$ (9) & 0 vs. 0 (9) \\
\hline Bello (2012) (43) & 182 & DCB vs. PES & $\begin{array}{l}1 \text { in DCB only vs. } \\
3 \text { in DCB + BMS } \\
\text { vs. } 12 \text { in PES }\end{array}$ & $\begin{array}{l}\text { LLL: } 0.08 \pm 0.38 \mathrm{~mm} \text { vs. } \\
0.29 \pm 0.44 \mathrm{~mm}^{\star}(6)\end{array}$ & 8.9 vs. $14.1 \%$ & $\begin{array}{l}4.4 \text { vs. } 7.6 \%(6) \\
6.7 \text { vs. } 13 \%(36)\end{array}$ & 0 vs. 0 (36) \\
\hline $\begin{array}{l}\text { Funatsu et al. } \\
(2017)(44)\end{array}$ & 135 & $\begin{array}{l}\text { DCB vs. } \\
\text { POBA }\end{array}$ & 3 in both groups & TVF: 3.4 vs. $10.3 \%$ (6) & $\begin{array}{l}13.3 \text { vs. } \\
42.5 \%{ }^{*}\end{array}$ & 2.3 vs. $10.3 \%$ (6) & 0 vs. $0(6)$ \\
\hline $\begin{array}{l}\text { BASKET-SMALL } 2 \\
(2018)(45)\end{array}$ & 758 & $\begin{array}{l}\text { DCB vs. } \\
\text { nDES }\end{array}$ & $\begin{array}{l}1 \text { in SAP and DCB } \\
\text { only vs. } 6 \text { in SAP } \\
\text { and DES vs. } 12 \text { in } \\
\text { ACS vs. } 3 \text { in DCB } \\
+ \text { BMS vs. } 6 \text { in } \\
\text { DCB + DES }\end{array}$ & $\begin{array}{l}\text { MACE: } 7.3 \text { vs. } 7.5 \%(12) \\
\text { MACE: } 15 \text { vs. } 15 \%(36)\end{array}$ & NA & $\begin{array}{l}3.4 \text { vs. } 4.5 \%(12) \\
9 \text { vs. } 9 \%(36)\end{array}$ & $\begin{array}{l}2 \text { vs. } 4(13) \\
2 \text { vs. } 6(36)\end{array}$ \\
\hline $\begin{array}{l}\text { Angiographic } \\
\text { analysis from the } \\
\text { BASKET-SMALL } 2 \\
(2020)(46)\end{array}$ & 111 & ditto & ditto & $\begin{array}{l}\text { DS: } 35.8 \text { vs. } 29.0 \% \text { ** } \\
\text { (median } 5.7 \text { ) }\end{array}$ & $\begin{array}{l}20.4 \text { vs. } \\
21.5 \%\end{array}$ & NA & NA \\
\hline $\begin{array}{l}\text { Restore SVD } \\
\text { China (2018) (47) }\end{array}$ & 230 & $\begin{array}{l}\text { DCB vs. } \\
\text { nDES }\end{array}$ & $\begin{array}{l}\text { At least } 6 \text { in both } \\
\text { groups }\end{array}$ & $\begin{array}{l}\text { DS: } 29.6 \pm 2.0 \text { vs. } 24.1 \pm \\
2.0 \% \text { (9) }\end{array}$ & 11.0 vs. $8.6 \%$ & $\begin{array}{l}4.4 \text { vs. } 2.6 \%(12) \\
5.2 \text { vs. } 2.8 \%(24)\end{array}$ & 0 vs. $0(24)$ \\
\hline $\begin{array}{l}\text { PICCOLETO II } \\
(2020)(48)\end{array}$ & 232 & DCB vs. EES & $\begin{array}{l}1 \text { in SAP and DCB } \\
\text { vs. } 6 \text { in EES vs. } 12 \\
\text { in ACS }\end{array}$ & $\begin{array}{l}\text { LLL: } 0.04 \pm 0.28 \mathrm{~mm} \text { vs. } \\
0.17 \pm 0.39 \mathrm{~mm}^{\star \star}(6)\end{array}$ & 6.3 vs. $6.5 \%$ & 5.6 vs. $5.6 \%(12)$ & 0 vs. 2 (12) \\
\hline
\end{tabular}

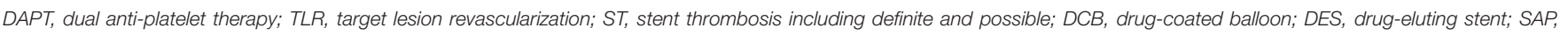

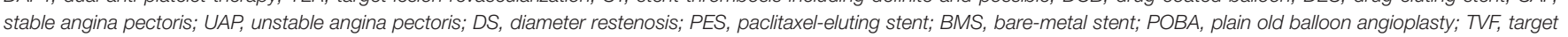
vessel failure; nDES, new-generation drug-eluting stent; ACS, acute coronary syndrome; MACE, major adverse cardiac events; EES, everolimus-eluting stent.

${ }^{\star} P<0.01$ vs. non-DCB group.

${ }^{\star \star} P<0.05$ vs. non-DCB group.

Drug-coated balloon angioplasty has the theoretical advantage of providing immediate and homogenous drug uptake, leaving no metal in the coronary artery and respecting the vessel anatomy, thus forming a "leave nothing behind" strategy in the treatment of do novo CAD (41). Many notable RCTs involving small vessel disease have used this strategy and all studies have shown the benefits of DCB except the PICCOLETO (42) (Table 3), which may be explained as the limitations of the first-generation Dior DCB (49). A recent meta-analysis showed that the use of $\mathrm{DCB}$ in the treatment of do novo CAD was associated with comparable clinical outcomes regardless of the indication or comparator device (50). However, there is still no clear conclusion regarding the duration of DAPT against small-vessel disease treated by DCB.

At present, the widely used postoperative DAPT strategy from clinical trials for the DCB treatment of small-vessel disease is the following: (1) DAPT duration in stable patients using DCB is 4 weeks; (2) DAPT duration in stable patients using DES is 6 months; (3) DAPT duration in patients with ACS is 12 months; and (4) DAPT duration in patients treated with a combination of DCB and BMS is 3 months, and in patients with DCB and DES is 6 months. Notable trials that used this strategy include PICCOLETO (42), BELLO (43), BASKET-SMALL 2 (45), and PICCOLETO II (48). Among these trials, the binary restenosis rates and TLR rates were comparable between the DCB and DES groups and were all low-probability events. It is important to acknowledge that patients treated with DCB and without stenting did not experience any thrombotic events in these trials, whereas only two stent thrombosis events were found in the BASKET-SMALL 2 trial during the 3-year follow-up (45). These results suggest that DCB may provide significant advantages over DES in treating small vessel disease, such as a lower risk of stent thrombosis, a shorter duration and less dependence on DAPT (43).

The RESTORE SVD China trial also demonstrated that the Restore DCB was non-inferior to the second-generation RESOLUTE Integrity DES $(47,51)$. However, DAPT was prescribed for at least 6 months after discharge from the hospital. During the 12-month follow-up, no significant difference was observed in the comparison of DAPT duration between the DCB and DES groups (91.4 vs. $94.7 \%$ ), which was partly due to the high proportion of unstable angina in this study and the high incidence of MACE in small vessels.

\section{Large Vessel de novo Coronary Artery Disease}

Many interventional cardiologists had doubts about the safety of $\mathrm{DCB}$ alone for large vessel de novo CAD because large coronary 
TABLE 4 | Characteristics of prospective trials of DCB for treatment of de novo coronary artery disease including large vessels.

\begin{tabular}{|c|c|c|c|c|c|c|c|}
\hline Trial (year) & $\begin{array}{l}\text { Patients, } \\
\qquad N\end{array}$ & Design & $\begin{array}{l}\text { DAPT duration } \\
\text { (months) }\end{array}$ & RVD, mm & $\begin{array}{l}\text { Primary endpoint } \\
\text { (follow-up, months) }\end{array}$ & $\begin{array}{l}\text { TLR, \% (follow-up, } \\
\text { months) }\end{array}$ & $\begin{array}{l}\text { ST, N } \\
\text { (follow-up, } \\
\text { months) }\end{array}$ \\
\hline $\begin{array}{l}\text { Randomized } \\
\text { control trial } \\
\text { Nishiyama et al. } \\
(2016)(53)\end{array}$ & 60 & DCB vs. EES & 8 in both groups & $\begin{array}{l}2.88 \pm 0.57 \mathrm{~mm} \\
\text { vs. } 2.72 \pm \\
0.64 \mathrm{~mm}\end{array}$ & $\begin{array}{l}\text { LLL: } 0.25 \pm 0.25 \mathrm{~mm} \\
\text { vs. } 0.37 \pm 0.40 \mathrm{~mm}(8)\end{array}$ & 0.0 vs. $6.1 \%(8)$ & NA \\
\hline $\begin{array}{l}\text { Gobić et al. (2017) } \\
\text { (54) }\end{array}$ & 75 & DCB vs. SES & 12 in both groups & $\begin{array}{l}2.61 \pm 0.49 \mathrm{~mm} \\
\text { vs. } 3.04 \pm \\
0.46 \mathrm{~mm}\end{array}$ & $\begin{array}{l}\text { LLL: }-0.09 \pm 0.08 \mathrm{~mm} \\
\text { vs. } 0.10 \pm 0.19 \mathrm{~mm}^{\star \star} \\
\text { (6) }\end{array}$ & 0.0 vs. $5.4 \%(6)$ & 0 vs. 2 (6) \\
\hline $\begin{array}{l}\text { REVELATION } \\
\text { (2019) (55) }\end{array}$ & 120 & DCB vs. DES & 9 in both groups & $\begin{array}{l}3.28 \pm 0.52 \mathrm{~mm} \\
\text { vs. } 3.20 \pm \\
0.48 \mathrm{~mm}\end{array}$ & $\begin{array}{l}\text { FFR: } 0.92 \pm 0.05 \text { vs. } \\
0.91 \pm 0.06(9)\end{array}$ & 3 vs. $2 \%(9)$ & 1 vs. 0 (9) \\
\hline DEBUT (2019) (9) & 220 & DCB vs. BMS & 1 in both groups & NA & $\begin{array}{l}\text { MACE: } 1 \text { vs. } 14 \%^{*}(9) \\
\text { MACE: } 4 \text { vs. } 14 \%^{* *}(12)\end{array}$ & $\begin{array}{l}0 \text { vs. } 6 \%{ }^{\star}(9) \\
2 \text { vs. } 6 \%(12)\end{array}$ & 0 vs. 2 (12) \\
\hline $\begin{array}{l}\text { Prospective } \\
\text { study } \\
\text { Cortese et al. } \\
(2015)(56)\end{array}$ & 156 & DCB & $\begin{array}{l}1 \text { in DCB only vs. } \\
6 \text { in DCB and } \\
\text { stent implantation }\end{array}$ & $\begin{array}{l}2.83(2.12-3.01) \\
\mathrm{mm}\end{array}$ & $\begin{array}{l}\text { Complete vessel } \\
\text { healing rate: } 93.8 \%(6)\end{array}$ & $\begin{array}{l}6.2 \% \text { in dissection } \\
\text { cohort vs. } 5.3 \% \text { in ALL } \\
\text { DCB }\end{array}$ & NA \\
\hline $\begin{array}{l}\text { Shin et al. (2016) } \\
(57)\end{array}$ & 66 & $\begin{array}{l}\text { DCB vs. } \\
\text { nDES }\end{array}$ & $\begin{array}{l}1.5 \text { in DCB vs. } 12 \\
\text { in DES vs. } 6 \text { in } \\
\text { BMS }\end{array}$ & $\begin{array}{l}2.69 \pm 0.45 \mathrm{~mm} \\
\text { vs. } 2.92 \pm \\
0.31 \mathrm{~mm}\end{array}$ & $\begin{array}{l}\text { LLL: } 0.05 \pm 0.27 \mathrm{~mm} \\
\text { vs. } 0.40 \pm 0.54 \mathrm{~mm}^{\star \star} \\
\text { (9) }\end{array}$ & 0.0 vs. $4.5 \%$ (12) & 0 vs. 0 (12) \\
\hline $\begin{array}{l}\text { Ann et al. (2016) } \\
(58)\end{array}$ & 27 & DCB & 1.5 & $2.58 \pm 0.45 \mathrm{~mm}$ & $\begin{array}{l}\text { LLL: } 0.02 \pm 0.27 \mathrm{~mm} \\
\text { (9) }\end{array}$ & $0.0 \%(9)$ & NA \\
\hline $\begin{array}{l}\text { Lu et al. (2019) } \\
\text { (59) }\end{array}$ & 92 & DCB & 6 & $3.32 \pm 0.46$ & $\begin{array}{l}\text { LLL: }-0.02 \pm 0.49 \mathrm{~mm} \\
\text { (9) }\end{array}$ & $4.3 \%(12)$ & NA \\
\hline $\begin{array}{l}\text { Rosenberg et al. } \\
(2019)(60)\end{array}$ & 686 & DCB & $\begin{array}{l}1 \text { in DCB vs. } 6 \text { in } \\
\text { DCB + stent } \\
\text { implantation }\end{array}$ & $\begin{array}{l}2.31 \pm 0.26 \mathrm{~mm} \text { in } \\
\text { small vessels vs. } \\
3.16 \pm 0.26 \mathrm{~mm} \text { in } \\
\text { large vessels }\end{array}$ & $\begin{array}{l}\text { TLR: } 2.4 \% \text { in small } \\
\text { vessels vs. } 1.8 \% \text { in } \\
\text { large vessels (9) }\end{array}$ & $\begin{array}{l}\text { TLR: } 2.4 \% \text { in small } \\
\text { vessels vs. } 1.8 \% \text { in } \\
\text { large vessels (9) }\end{array}$ & $\begin{array}{l}1 \text { in small } \\
\text { vessels vs. } 1 \\
\text { in large } \\
\text { vessels (9) }\end{array}$ \\
\hline
\end{tabular}

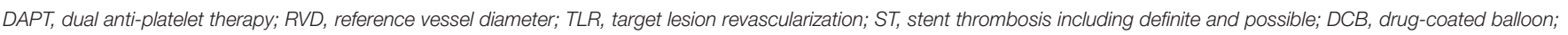

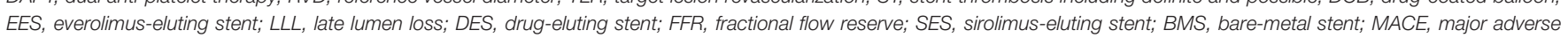
cardiac events.

${ }^{\star} P<0.01$ vs. non-DCB group.

${ }^{* *} P<0.05$ vs. non-DCB group.

arteries have more smooth muscle fibers than small vessel arteries and are more prone to recoil and dissection, which may lead to acute occlusion or restenosis of blood vessels (52). Although randomized data for comparing DCB and DES in the treatment of large vessels are still lacking, there are variable proportions of large vessels that were treated using the DCB-only approach in studies, which creates growing evidence for the safety and efficacy of the DCB-only strategy for the treatment of large coronary arteries. The durations of DAPT in these trials ranged from 1 to 12 months (Table 4).

A recent prospective large-scale multicenter trial demonstrated that DCB as a stand-alone-therapy showed similar efficacy on large and small vessels $(60,61)$. In this trial, standard DAPT duration was recommended for 1 month in DCB-only treatment and a minimum of 6 months when additional stents were implanted. During the follow-up, in the large vessel group, the DAPT duration was $2.7 \pm 1.6$ months, whereas in the small vessel group, the DAPT duration was $2.8 \pm 1.6$ months $(p=0.583)$. Meanwhile, this trial observed that around half of each group had a recommendation for 4 weeks of DAPT (>2.75 mm: $53.3 \%$ vs. $\leq 2.75 \mathrm{~mm}: 48.1 \%, p$ $=\mathrm{ns}$ ). Only one case of stent thrombosis occurred in each group. The DEBUT trial which showed DCB-only coronary intervention was superior to BMS in patients at bleeding risk, was also administered 1-month of DAPT for all patients (9). In patients assigned to DCB, 64\% were treated with a DCB that was $3 \mathrm{~mm}$ or larger diameter, and stent thrombosis occurred in none of them. A short duration of DAPT after DCB angioplasty was recommended in the other three trials without any stent thrombosis found and low risk rates of clinical events (56-58). These results indicate that short-term DAPT may be feasible and safe. On the contrary, some trials recommended DAPT for 6 months or longer, and they also did not find stent thrombosis during follow-up (53-55). These trials chose a longer DAPT duration because most patients in these trials were admitted to the hospital for ACS.

\section{Other Clinical Situations}

\section{Chronic Total Occlusions}

Chronic Total Occlusions (CTOs) of the coronary arteries remain one of interventional cardiologists' biggest challenges and some scholars have also attempted to apply the DCB-only strategy to 
CTO $(62,63)$. A prospective trial led by Köln et al. showed that the DCB-only strategy as a treatment option for CTO was feasible and well-tolerated (63). Most patients received DAPT for at least 4 weeks and 4 of 34 patients had contraindications for DAPT who received only lifelong aspirin in this trial. Restenosis occurred in $11.8 \%$ of all patients, re-occlusion in $5.9 \%$, TLR in $17.6 \%$, and no stent thrombosis was found.

\section{High Bleeding Risk}

An all-comers retrospective study that contained 52\% highbleeding-risk patients showed the safety and feasibility of shortterm DAPT after DCB angioplasty for both stable CAD and ACS (64). The median and mean durations of DAPT were 1 and 2.8 months in the stable CAD population and 1 and 3.3 months in the ACS population. The MACE rate was 9.8 and $14.8 \%$ at 12 and 24 months with 2.1 and $3.1 \%$ TLR rates, respectively. Recently, the DEBUT trial demonstrated that DCB was superior to BMS for the treatment of de novo coronary artery lesions in patients with high bleeding risk (9). The duration of DAPT was 1 month in patients with stable CAD and ACS in both groups. For ACS patients receiving anticoagulation therapy, the duration of aspirin was 6 months. At 9 months, the MACE and TLR rates were 1 and $0 \%$ in the DCB group and 14 and $6 \%$ in the BMS group, respectively. One case of stent thrombosis occurred in each group.

\section{Duration in ACS}

Although receiving second-generation DES is the most common option for the treatment of patients with ACS and is generally considered the optimal strategy (65), some small sample size clinical trials have attempted to use the DCB-only strategy in primary percutaneous coronary intervention (PPCI) $(54,55,66-$ 68). Nicola et al. conducted the first study of a DCB-only strategy in the setting of PPCI, and DPAT was scheduled to be continued for 12 months (66). This study showed good 1-year clinical results with only five MACEs occurring, including three TLR and one acute stent thrombosis, but additional stenting was performed in half of the patients. Recently, the REVELATION study shown that DCB was non-inferior to the second-generation DES in the treatment of ST-segment elevated myocardial infarction patients (55). All patients were on DAPT and/or combined with oral anticoagulation for at least 1 year. Up to the 9-month follow-up, only three patients required TLR (one in the DES group and two in the DCB group) and only one thrombotic event was found in the DCB group. The 1-year duration of DAPT seemed to be a reasonable option based on the guideline recommendations and the results of existing clinical trials.

However, it remains a question whether DAPT duration for ACS patients is worth reducing or prolonging. A recent meta-analysis of the duration of DAPT after PCI with DES demonstrated that short-term DAPT presented similar efficacy and safety to standard-term DAPT for patients with ACS (69).

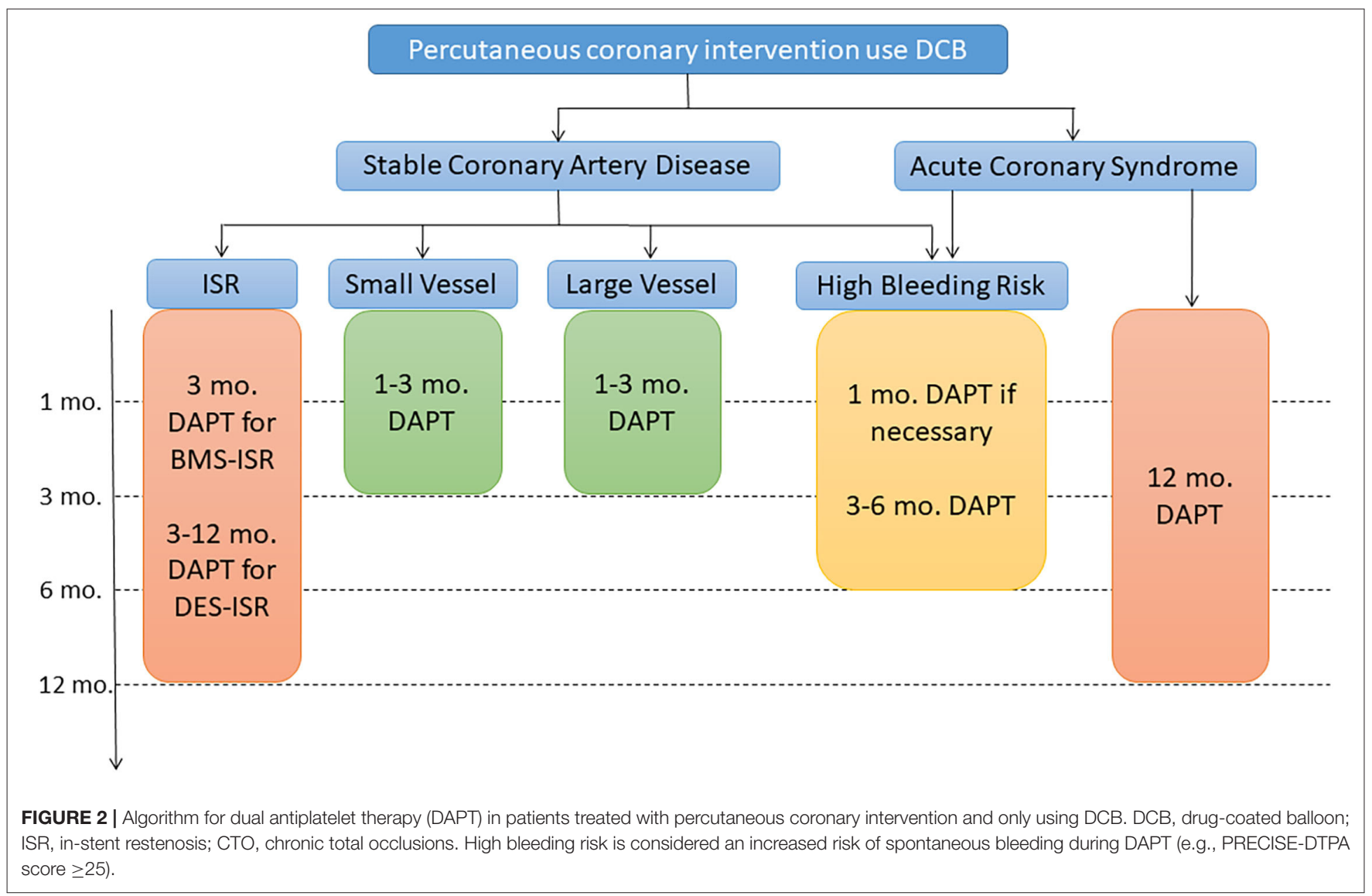


In the DEBUT trial, $46 \%$ of patients treated with DCB only were diagnosed with ACS (9). All patients in this trial were recommended to undergo only a 1-month duration of DAPT, and the results showed low MACE rates with no TLR event at 9 months. Meanwhile, no stent thrombosis event occurred during the follow-up. In another retrospective study which contained 55\% of ACS patients showed a 12\% MACE rate and $2.8 \%$ TLR rate at 12 months (64). The median and mean durations of DAPT were 1 and 3.3 months in the ACS population. Of note, half of the patients had at least one risk factor for bleeding. Furthermore, about $4 \%$ of patients did not receive any ADP receptor blockers at all during or after PCI due to a contraindication for DAPT. Meanwhile, the European Society of Cardiology Guidelines also suggest that patients at high or moderate ischemic risk who have well-tolerated DAPT within the first year after myocardial infarction may benefit from more intense antithrombotic therapy beyond 12 months from the acute event (70). For this kind of patients (e.g., age $\geq 65$ years and multivessel coronary disease), aspirin 75-100 mg with ticagrelor $60 \mathrm{mg}$ twice daily or rivaroxaban $2.5 \mathrm{mg}$ twice daily may be administered, which would reduce the ischemic risk with no major bleeding events and infrequent minor/minimal bleeding $(71,72)$. Whether prolonging or reducing the duration of DAPT, it is important to tailor the treatment to each patient to get the best benefits of DAPT.

\section{Duration for New-Generation Sirolimus DCB}

Thus far, paclitaxel, as a cytotoxic agent, is the preferred drug for balloon coating and has been widely cited in cardiovascular interventional therapies. With the growing clinical research evidence of sirolimus-coated balloon (SCB), their clinical feasibility and safety are being increasingly recognized. The SABRE trial showed excellent procedural success for the Virtue sirolimus-eluting angioplasty balloon in the treatment of ISR (73). In this trial, DAPT was continued for at least 3 months and the MACE rate was $14.3 \%$ at 12 months, with a $12.2 \%$ TLR rate. Soon after that, an RCT that compared a crystalline coating SCB with paclitaxel-coated balloon (PCB) demonstrated similar angiographic outcomes in the treatment of coronary DES-ISR (74). Interestingly, DAPT was recommended for 1 months in stable patients and 12 months in cases of ACS. The MACE and TLR rates were similar between the two groups, and only one stent thrombosis occurred in the PCB group. Two other large prospective trials that enrolled a real-world, all-comer patient population also showed the safety and efficacy of SCB, both in

\section{REFERENCES}

1. Scheller B, Speck U, Abramjuk C, Bernhardt U, Bohm M, Nickenig G. Paclitaxel balloon coating, a novel method for prevention and therapy of restenosis. Circulation. (2004) 110:8104. doi: 10.1161/01.CIR.0000138929.71660.E0

2. Scheller B, Hehrlein C, Bocksch W, Rutsch W, Haghi D, Dietz U, et al. Treatment of coronary in-stent restenosis with a paclitaxel-coated balloon catheter. N Engl J Med. (2006) 355:2113-24. doi: 10.1056/NEJMoa061254 patients with ISR or de novo lesions $(75,76)$. The Nanolutè study evaluated the clinical performance of a novel SCB (Concept Medical Research Private Limited, India) for the treatment of ISR and de novo coronary lesions. Dual antiplatelet therapy was recommended for 3-12 months in this trial (75). The MACE rate was $4.2 \%$ with $3.2 \%$ TLR at 2 years. The EASTBOURNE registry also evaluated this kind of SCB and obtained similar results as the Nanolutè study (76). In this trial, DAPT duration was prescribed for a minimum of 1 and 6 months in the case of additional stent implantation. As for ACS patients, DAPT duration was prescribed according to the current guidelines.

\section{CONCLUSIONS AND PERSPECTIVE}

As DCB technology is playing an increasingly important role in PCI, standardizing postoperative drug treatment is essential. Defining the optimal duration of DAPT after DCB-only angioplasty remains an interesting question but the currently available evidence is limited. Here, we give a simple summary with suggestions for DAPT duration in the different clinical scenarios based on current evidence (Figure 2).

For a decade, we have been passionate about defining the optimal duration of DAPT after stenting and have conducted many RCTs. Now, it is time to focus on the optimal duration of DAPT after DCB-only angioplasty. Meanwhile, with the advancement of DCB technology and the discovery of potent antiplatelet drugs, the DAPT approach may shift to a new paradigm of single antiplatelet therapy. It is necessary to explore the feasibility of single antiplatelet therapy after DCBonly angioplasty.

\section{AUTHOR CONTRIBUTIONS}

All authors contributed to the manuscript production and in the final revision. YZ, QD, DC, and YX structured the manuscript giving contribute to table, figures, and text editing. JJ, XZ, and YZ revisited the article implementing the final manuscript form.

\section{FUNDING}

JJ was supported by grant from the National Natural Science Foundation of China (No. 82170332) and Key Research and Development Program of Zhejiang Province (No. 2020C03016). $\mathrm{XZ}$ was supported by grant from the National Natural Science Foundation for young scientists of China (No. 82100346).
3. Tepe G, Zeller T, Albrecht T, Heller S, Schwarzwalder U, Beregi JP, et al. Local delivery of paclitaxel to inhibit restenosis during angioplasty of the leg. $N$ Engl J Med. (2008) 358:689-99. doi: 10.1056/NEJMoa0706356

4. Nestelberger T, Kaiser C, Jeger R. Drug-coated balloons in cardiovascular disease: benefits, challenges, and clinical applications. Expert Opin Drug Deliv. (2020) 17:201-11. doi: 10.1080/17425247.2020.1714590

5. Neumann FJ, Sousa-Uva M, Ahlsson A, Alfonso F, Banning AP, Benedetto U, et al. $2018 \mathrm{ESC}$ /EACTS Guidelines on myocardial revascularization. Eur Heart J. (2019) 40:87-165. doi: 10.1093/eurheartj/ehy855 
6. Jeger RV, Eccleshall S, Wan Ahmad WA, Ge J, Poerner TC, Shin ES, et al. Drug-coated balloons for coronary artery disease: third report of the international DCB consensus group. JACC Cardiovasc Interv. (2020) 13:1391402. doi: 10.1016/j.jcin.2020.02.043

7. Her AY, Shin ES, Bang LH, Nuruddin AA, Tang Q, Hsieh IC, et al. Drug-coated balloon treatment in coronary artery disease: recommendations from an asia-pacific consensus group. Cardiol J. (2021) 28:136-49. doi: 10.5603/CJ.a2019.0093

8. Levine GN, Bates ER, Bittl JA, Brindis RG, Fihn SD, Fleisher LA, et al. 2016 ACC/AHA Guideline Focused Update on Duration of Dual Antiplatelet Therapy in Patients With Coronary Artery Disease: A Report of the American College of Cardiology/American Heart Association Task Force on Clinical Practice Guidelines: An Update of the 2011 ACCF/AHA/SCAI Guideline for Percutaneous Coronary Intervention, 2011 ACCF/AHA Guideline for Coronary Artery Bypass Graft Surgery, 2012 ACC/AHA/ACP/AATS/PCNA/SCAI/STS Guideline for the Diagnosis and Management of Patients With Stable Ischemic Heart Disease, 2013 ACCF/AHA Guideline for the Management of ST-Elevation Myocardial Infarction, 2014 AHA/ACC Guideline for the Management of Patients With Non-ST-Elevation Acute Coronary Syndromes, and 2014 ACC/AHA Guideline on Perioperative Cardiovascular Evaluation and Management of Patients Undergoing Noncardiac Surgery. Circulation. (2016) 134:e12355. doi: 10.1161/CIR.0000000000000404

9. Rissanen TT, Uskela S, Eränen J, Mäntylä, P, Olli A, Romppanen H, et al. Drugcoated balloon for treatment of de-novo coronary artery lesions in patients with high bleeding risk (DEBUT): a single-blind, randomised, non-inferiority trial. Lancet. (2019) 394:230-9. doi: 10.1016/S0140-6736(19)31126-2

10. Kleber F, Mathey D, Rittger H, Scheller B. How to use the drug-eluting balloon: recommendations by the German consensus group. EuroIntervention. (2011) 7:K125-8. doi: 10.4244/EIJV7SKA21

11. Kleber FX, Rittger H, Bonaventura K, Zeymer U, Wöhrle J, Jeger R, et al. Drug-coated balloons for treatment of coronary artery disease: updated recommendations from a consensus group. Clin Res Cardiol. (2013) 102:78597. doi: 10.1007/s00392-013-0609-7

12. Cortese B, Berti S, Biondi-Zoccai G, Colombo A, Limbruno U, Bedogni F, et al. Drug-coated balloon treatment of coronary artery disease: a position paper of the Italian Society of Interventional Cardiology. Catheter Cardiovasc Interv. (2014) 83:427-35. doi: 10.1002/ccd.25149

13. Valgimigli M, Bueno H, Byrne RA, Collet JP, Costa F, Jeppsson A, et al. 2017 ESC focused update on dual antiplatelet therapy in coronary artery disease developed in collaboration with EACTS: the Task Force for dual antiplatelet therapy in coronary artery disease of the European Society of Cardiology (ESC) and of the European Association for Cardio-Thoracic Surgery (EACTS). Eur Heart J. (2018) 39:213-60. doi: 10.1093/eurheartj/ehx419

14. Varga-Szabo D, Pleines I, Nieswandt B. Cell adhesion mechanisms in platelets. Arterioscler Thromb Vasc Biol. (2008) 28:403-12. doi: 10.1161/ATVBAHA.107.150474

15. Angiolillo DJ, Ueno M, Goto S. Basic principles of platelet biology and clinical implications. Circ J. (2010) 74:597-607. doi: 10.1253/circj.CJ09-0982

16. Angiolillo DJ, Capodanno D, Goto S. Platelet thrombin receptor antagonism and atherothrombosis. Eur Heart J. (2010) 31:1728. doi: 10.1093/eurheartj/ehp504

17. Ueno M, Kodali M, Tello-Montoliu A, Angiolillo DJ. Role of platelets and antiplatelet therapy in cardiovascular disease. J Atheroscler Thromb. (2011) 18:431-42. doi: 10.5551/jat.7633

18. Byrne RA, Joner M, Kastrati A. Stent thrombosis and restenosis: what have we learned and where are we going? The Andreas Gruntzig lecture ESC 2014. Eur Heart J. (2015) 36:3320-31. doi: 10.1093/eurheartj/ehv511

19. Kufner S, Joner M, Thannheimer A, Hoppmann P, Ibrahim T, Mayer K, et al. Ten-year clinical outcomes from a trial of three limus-eluting stents with different polymer coatings in patients with coronary artery disease: results from the ISAR-TEST 4 randomized trial. Circulation. (2019) 139:32533. doi: 10.1161/CIRCULATIONAHA.118.038065

20. Alfonso F, Byrne RA, Rivero F, Kastrati A. Current treatment of in-stent restenosis. J Am Coll Cardiol. (2014) 63:265973. doi: 10.1016/j.jacc.2014.02.545
21. Giacoppo D, Alfonso F, Xu B, Claessen B, Adriaenssens T, Jensen C, et al. Drug-coated balloon angioplasty versus drug-eluting stent implantation in patients with coronary stent restenosis. J Am Coll Cardiol. (2020) 75:266478. doi: 10.1016/j.jacc.2020.04.006

22. Scheller B, Clever YP, Kelsch B, Hehrlein C, Bocksch W, Rutsch W, et al. Long-term follow-up after treatment of coronary in-stent restenosis with a paclitaxel-coated balloon catheter. JACC Cardiovasc Interv. (2012) 5:32330. doi: 10.1016/j.jcin.2012.01.008

23. Unverdorben M, Vallbracht C, Cremers B, Heuer H, Hengstenberg C, Maikowski C, et al. Paclitaxel-coated balloon catheter versus paclitaxel-coated stent for the treatment of coronary in-stent restenosis. Circulation. (2009) 119:2986-94. doi: 10.1161/CIRCULATIONAHA.108.839282

24. Alfonso F, Perez-Vizcayno MJ, Cardenas AB, Garcia Del Blanco, Seidelberger $\mathrm{B}$, Iniguez $\mathrm{A}$, et al. A randomized comparison of drug-eluting balloon versus everolimus-eluting stent in patients with bare-metal stent-in-stent restenosis: the RIBS V clinical trial (restenosis intra-stent of bare metal stents: paclitaxeleluting balloon vs everolimus-eluting stent). J Am Coll Cardiol. (2014) 63:1378-86. doi: 10.1016/j.jacc.2013.12.006

25. Scheller B, Fontaine T, Mangner N, Hoffmann S, Bonaventura K, Clever YP, et al. A novel drug-coated scoring balloon for the treatment of coronary in-stent restenosis: results from the multi-center randomized controlled PATENT-C first in human trial. Catheter Cardiovasc Interv. (2016) 88:519. doi: $10.1002 / \mathrm{ccd} .26216$

26. Pleva L, Kukla P, Kusnierova P, Zapletalova J, Hlinomaz O. Comparison of the efficacy of paclitaxel-eluting balloon catheters and everolimuseluting stents in the treatment of coronary in-stent restenosis: the treatment of in-stent restenosis study. Circ Cardiovasc Interv. (2016) 9:e003316. doi: 10.1161/CIRCINTERVENTIONS.115.003316

27. Rittger H, Brachmann J, Sinha AM, Waliszewski M, Ohlow M, Brugger A, et al. A randomized, multicenter, single-blinded trial comparing paclitaxelcoated balloon angioplasty with plain balloon angioplasty in drug-eluting stent restenosis: the PEPCAD-DES study. J Am Coll Cardiol. (2012) 59:137782. doi: 10.1016/j.jacc.2012.01.015

28. Byrne RA, Neumann F-J, Mehilli J, Pinieck S, Wolff B, Tiroch K, et al. Paclitaxel-eluting balloons, paclitaxel-eluting stents, and balloon angioplasty in patients with restenosis after implantation of a drug-eluting stent (ISAR-DESIRE 3): a randomised, open-label trial. Lancet. (2013) 381:4617. doi: 10.1016/S0140-6736(12)61964-3

29. Xu B, Gao R, Wang J, Yang Y, Chen S, Liu B, et al. A prospective, multicenter, randomized trial of paclitaxel-coated balloon versus paclitaxeleluting stent for the treatment of drug-eluting stent in-stent restenosis: results from the PEPCAD China ISR trial. JACC Cardiovasc Interv. (2014) 7:20411. doi: 10.1016/j.jcin.2013.08.011

30. Alfonso F, Perez-Vizcayno MJ, Cardenas A, Garcia del Blanco B, GarciaTouchard A, Lopez-Minguez JR, et al. A prospective randomized trial of drug-eluting balloons versus everolimus-eluting stents in patients with instent restenosis of drug-eluting stents: the RIBS IV randomized clinical trial. $J$ Am Coll Cardiol. (2015) 66:23-33. doi: 10.1016/j.jacc.2015.04.063

31. Kufner S, Joner M, Schneider S, Tolg R, Zrenner B, Repp J, et al. Neointimal modification with scoring balloon and efficacy of drug-coated balloon therapy in patients with restenosis in drug-eluting coronary stents: a randomized controlled trial. JACC Cardiovasc Interv. (2017) 10:133240. doi: 10.1016/j.jcin,0.2017.04.024

32. Wong YTA, Kang D-Y, Lee JB, Rha S-W, Hong YJ, Shin E-S, et al. Comparison of drug-eluting stents and drug-coated balloon for the treatment of drugeluting coronary stent restenosis: a randomized RESTORE trial. Am Heart J. (2018) 197:35-42. doi: 10.1016/j.ahj.2017.11.008

33. Baan J Jr, Claessen BE, Dijk KB, Vendrik J, van der Schaaf RJ, Meuwissen $\mathrm{M}$, et al. A randomized comparison of paclitaxel-eluting balloon versus everolimus-eluting stent for the treatment of any instent restenosis: the DARE trial. JACC Cardiovasc Interv. (2018) 11:27583. doi: 10.1016/j.jcin.2017.10.024

34. Jensen CJ, Richardt G, Tolg R, Erglis A, Skurk C, Jung W, et al. Angiographic and clinical performance of a paclitaxel-coated balloon compared to a secondgeneration sirolimus-eluting stent in patients with in-stent restenosis: the BIOLUX randomised controlled trial. EuroIntervention. (2018) 14:1096103. doi: 10.4244/EIJ-D-17-01079 
35. Unverdorben M, Vallbracht C, Cremers B, Heuer H, Hengstenberg C, Maikowski C, et al. Paclitaxel-coated balloon catheter versus paclitaxelcoated stent for the treatment of coronary in-stent restenosis: the threeyear results of the PEPCAD II ISR study. EuroIntervention. (2015) 11:92634. doi: 10.4244/EIJY14M08_12

36. Alfonso F, Perez-Vizcayno MJ, Cuesta J, Garcia Del Blanco B, GarciaTouchard A, Lopez-Minguez JR, et al. 3-year clinical follow-up of the ribs IV clinical trial: a prospective randomized study of drug-eluting balloons versus everolimus-eluting stents in patients with in-stent restenosis in coronary arteries previously treated with drug-eluting stents. JACC Cardiovasc Interv. (2018) 11:981-91. doi: 10.1016/j.jcin.2018.02.037

37. Rittger H, Waliszewski M, Brachmann J, Hohenforst-Schmidt W, Ohlow M, Brugger A, et al. Long-term outcomes after treatment with a paclitaxelcoated balloon versus balloon angioplasty: insights from the pepcaddes study (treatment of drug-eluting stent [DES] in-stent restenosis with sequent please paclitaxel-coated percutaneous transluminal coronary angioplasty [PTCA] catheter). JACC Cardiovasc Interv. (2015) 8:1695700. doi: 10.1016/j.jcin.2015.07.023

38. Xu B, Qian J, Ge J, Wang J, Chen F, Chen J, et al. Two-year results and subgroup analyses of the PEPCAD China in-stent restenosis trial: a prospective, multicenter, randomized trial for the treatment of drug-eluting stent in-stent restenosis. Catheter Cardiovasc Interv. (2016) 87(Suppl 1):6249. doi: 10.1002/ccd.26401

39. Akiyama T, Moussa I, Reimers B, Ferraro M, Kobayashi Y, Blengino S, et al. Angiographic and clinical outcome following coronary stenting of small vessels: a comparison with coronary stenting of large vessels. J Am Coll Cardiol. (1998) 32:1610-8. doi: 10.1016/S0735-1097(98)00444-6

40. Biondi-Zoccai G, Moretti C, Abbate A, Sheiban I. Percutaneous coronary intervention for small vessel coronary artery disease. Cardiovasc Revasc Med. (2010) 11:189-98. doi: 10.1016/j.carrev.2009.04.007

41. Yerasi C, Case BC, Forrestal BJ, Torguson R, Weintraub WS, GarciaGarcia HM, et al. Drug-coated balloon for de novo coronary artery disease: JACC state-of-the-art review. J Am Coll Cardiol. (2020) 75:106173. doi: 10.1016/j.jacc.2019.12.046

42. Cortese B, Micheli A, Picchi A, Coppolaro A, Bandinelli L, Severi S, et al. Paclitaxel-coated balloon versus drug-eluting stent during PCI of small coronary vessels, a prospective randomised clinical trial. The PICCOLETO study. Heart. (2010) 96:1291-6. doi: 10.1136/hrt.2010.195057

43. Latib A, Colombo A, Castriota F, Micari A, Cremonesi A, De Felice F, et al. A randomized multicenter study comparing a paclitaxel drug-eluting balloon with a paclitaxel-eluting stent in small coronary vessels: the BELLO (balloon elution and late loss optimization) study. J Am Coll Cardiol. (2012) 60:2473-80. doi: 10.1016/j.jacc.2012.09.020

44. Funatsu A, Nakamura S, Inoue N, Nanto S, Nakamura M, Iwabuchi M, et al. A multicenter randomized comparison of paclitaxel-coated balloon with plain balloon angioplasty in patients with small vessel disease. Clin Res Cardiol. (2017) 106:824-32. doi: 10.1007/s00392-017-1126-x

45. Jeger RV, Farah A, Ohlow MA, Mangner N, Möbius-Winkler S, Leibundgut G, et al. (2018). Drug-coated balloons for small coronary artery disease (BASKET-SMALL 2): an open-label randomised non-inferiority trial. Lancet 392:849-56. doi: 10.1016/S0140-6736(18)31719-7

46. Fahrni G, Scheller B, Coslovsky M, Gilgen N, Farah A, Ohlow MA, et al. Drugcoated balloon versus drug-eluting stent in small coronary artery lesions: angiographic analysis from the BASKET-SMALL 2 trial. Clin Res Cardiol. (2020) 109:1114-24. doi: 10.1007/s00392-020-01603-2

47. Tang Y, Qiao S, Su X, Chen Y, Jin Z, Chen H, et al. Drug-coated balloon versus drug-eluting stent for small-vessel disease: the RESTORE SVD China randomized trial. JACC Cardiovasc Interv. (2018) 11:238192. doi: 10.1016/j.jcin.2018.09.009

48. Cortese B, Di Palma G, Guimaraes MG, Piraino D, Orrego PS, Buccheri D, et al. Drug-coated balloon versus drug-eluting stent for small coronary vessel disease: PICCOLETO II randomized clinical trial. JACC Cardiovasc Interv. (2020) 13:2840-9. doi: 10.1016/j.jcin.2020.08.035

49. Cortese, B. The PICCOLETO study and beyond. EuroIntervention. (2011) 7(Suppl K):K53-6. doi: 10.4244/EIJV7SKA9

50. Elgendy IY, Gad MM, Elgendy AY, Mahmoud A, Mahmoud AN, Cuesta J, et al. Clinical and angiographic outcomes with drug-coated balloons for de novo coronary lesions: a meta-analysis of randomized clinical trials. J Am Heart Assoc. (2020) 9:e016224. doi: 10.1161/JAHA.120. 016224

51. Tian J, Tang YD, Qiao S, Su X, Chen Y, Jin Z, et al. Two-year followup of a randomized multicenter study comparing a drug-coated balloon with a drug-eluting stent in native small coronary vessels: the RESTORE small vessel disease China trial. Catheter Cardiovasc Interv. (2020) 95(Suppl 1):587-97. doi: 10.1002/ccd.28705

52. Yu X, Ji F, Xu F, Zhang W, Wang X, Lu D, et al. Treatment of large de novo coronary lesions with paclitaxel-coated balloon only: results from a Chinese Institute. Clin Res Cardiol. (2019) 108:23443. doi: 10.1007/s00392-018-1346-8

53. Nishiyama N, Komatsu T, Kuroyanagi T, Fujikake A, Komatsu S, Nakamura $\mathrm{H}$, et al. Clinical value of drug-coated balloon angioplasty for de novo lesions in patients with coronary artery disease. Int J Cardiol. (2016) 222:1138. doi: 10.1016/j.ijcard.2016.07.156

54. Gobic D, Tomulic V, Lulic D, Zidan D, Brusich S, Jakljevic T, et al. Drug-coated balloon versus drug-eluting stent in primary percutaneous coronary intervention: a feasibility study. Am J Med Sci. (2017) 354:55360. doi: 10.1016/j.amjms.2017.07.005

55. Vos NS, Fagel ND, Amoroso G, Herrman JR, Patterson MS, Piers LH, et al. Paclitaxel-coated balloon angioplasty versus drug-eluting stent in acute myocardial infarction: the REVELATION randomized trial. JACC Cardiovasc Interv. (2019) 12:1691-9. doi: 10.1016/j.jcin.2019.04.016

56. Cortese B, Silva Orrego P, Agostoni P, Buccheri D, Piraino D, Andolina $\mathrm{G}$, et al. Effect of drug-coated balloons in native coronary artery disease left with a dissection. JACC Cardiovasc Interv. (2015) 8:20039. doi: 10.1016/j.jcin.2015.08.029

57. Shin ES, Ann SH, Balbir Singh G, Lim KH, Kleber FX, Koo BK. Fractional flow reserve-guided paclitaxel-coated balloon treatment for de novo coronary lesions. Catheter Cardiovasc Interv. (2016) 88:193200. doi: 10.1002/ccd.26257

58. Ann SH, Balbir Singh G, Lim KH, Koo BK, Shin ES. Anatomical and physiological changes after paclitaxel-coated balloon for atherosclerotic de novo coronary lesions: serial IVUS-VH and FFR study. PLoS ONE. (2016) 11:e0147057. doi: 10.1371/journal.pone.0147057

59. Lu W, Zhu Y, Han Z, Sun G, Qin X, Wang Z, et al. Short-term outcomes from drug-coated balloon for coronary de novo lesions in large vessels. J Cardiol. (2019) 73:151-5. doi: 10.1016/j.jjcc.2018.07.008

60. Rosenberg M, Waliszewski M, Krackhardt F, Chin K, Wan Ahmad WA, Caramanno G, et al. Drug coated balloon-only strategy in de novo lesions of large coronary vessels. J Interv Cardiol. (2019) 2019:6548696. doi: 10.1155/2019/6548696

61. Rosenberg M, Waliszewski M, Chin KW, Ahmad AW, Caramanno G, Milazzo D, et al. Prospective, large-scale multicenter trial for the use of drug-coated balloons in coronary lesions: the DCB-only all-comers registry. Catheter Cardiovasc Interv. (2019) 93:181-8. doi: 10.1002/ccd. 27724

62. Cortese B, Buccheri D, Piraino D, Silva-Orrego P. Drug-coated balloon without stent implantation for chronic total occlusion of coronary arteries: description of a new strategy with an optical coherence tomography assistance. Int J Cardiol. (2015) 191:75-6. doi: 10.1016/j.ijcard.2015. 04.278

63. Koln PJ, Scheller B, Liew HB, Rissanen TT, Ahmad WA, Weser R, et al. Treatment of chronic total occlusions in native coronary arteries by drugcoated balloons without stenting - a feasibility and safety study. Int J Cardiol. (2016) 225:262-7. doi: 10.1016/j.ijcard.2016.09.105

64. Uskela S, Karkkainen JM, Eranen J, Siljander A, Mantyla P, Mustonen J, et al. Percutaneous coronary intervention with drug-coated balloon-only strategy in stable coronary artery disease and in acute coronary syndromes: an all-comers registry study. Catheter Cardiovasc Interv. (2019) 93:893900. doi: $10.1002 / \mathrm{ccd} .27950$

65. Boersma EG. Primary coronary angioplasty vs. thrombolysis, does time matter? A pooled analysis of randomized clinical trials comparing primary percutaneous coronary intervention and in-hospital fibrinolysis in acute myocardial infarction patients. Eur Heart J. (2006) 27:77988. doi: 10.1093/eurheartj/ehi810

66. Vos NS, Dirksen MT, Vink MA, van Nooijen FC, Amoroso G, Herrman JP, et al. Safety and feasibility of a PAclitaxel-eluting balloon angioplasty in 
primary percutaneous coronary intervention in Amsterdam (PAPPA): oneyear clinical outcome of a pilot study. EuroIntervention. (2014) 10:58490. doi: 10.4244/EIJV10I5A101

67. Scheller B, Ohlow MA, Ewen S, Kische S, Rudolph TK, Clever YP, et al. Bare metal or drug-eluting stent versus drug-coated balloon in non-ST-elevation myocardial infarction: the randomised PEPCAD NSTEMI trial. EuroIntervention. (2020) 15:1527-33. doi: 10.4244/EIJ-D-1900723

68. Harima A, Sairaku A, Inoue I, Nishioka K, Oka T, Nakama Y, et al. Real-life experience of a stent-less revascularization strategy using a combination of excimer laser and drug-coated balloon for patients with acute coronary syndrome. J Interv Cardiol. (2018) 31:284-92. doi: 10.1111/joic. 12495

69. Yin SH, Xu P, Wang B, Lu Y, Wu QY, Zhou ML, et al. Duration of dual antiplatelet therapy after percutaneous coronary intervention with drugeluting stent: systematic review and network meta-analysis. BMJ. (2019) 365:12222. doi: 10.1136/bmj.12222

70. Knuuti J, Wijns W, Saraste A, Capodanno D, Barbato E, FunckBrentano C, et al. 2019 ESC guidelines for the diagnosis and management of chronic coronary syndromes. Eur Heart J. (2020) 41:407-77. doi: 10.1093/eurheartj/ehz425

71. Cesaro A, Taglialatela V, Gragnano F, Moscarella E, Fimiani F, Conte $\mathrm{M}$, et al. Low-dose ticagrelor in patients with high ischemic risk and previous myocardial infarction: a multicenter prospective real-world observational study. J Cardiovasc Pharmacol. (2020) 76:173-80. doi: 10.1097/FJC.0000000000000856

72. Cesaro A, Gragnano F, Calabro P, Moscarella E, Santelli F, Fimiani F, et al. Prevalence and clinical implications of eligibility criteria for prolonged dual antithrombotic therapy in patients with PEGASUS and COMPASS phenotypes: insights from the START-ANTIPLATELET registry. Int J Cardiol. (2021) 345:7-13. doi: 10.1016/j.ijcard.2021.10.138

73. Verheye S, Vrolix M, Kumsars I, Erglis A, Sondore D, Agostoni P, et al. The SABRE trial (sirolimus angioplasty balloon for coronary in-stent restenosis): angiographic results and 1-year clinical outcomes. JACC Cardiovasc Interv. (2017) 10:2029-37. doi: 10.1016/j.jcin.2017.06.021

74. Ali RM, Abdul Kader M, Wan Ahmad WA, Ong TK, Liew HB, Omar $\mathrm{AF}$, et al. Treatment of coronary drug-eluting stent restenosis by a sirolimus- or paclitaxel-coated balloon. JACC Cardiovasc Interv. (2019) 12:558-66. doi: 10.1016/j.jcin.2018.11.040

75. El-Mokdad R, di Palma G, Cortese B. Long-term follow-up after sirolimus-coated balloon use for coronary artery disease. Final results of the Nanolute study. Catheter Cardiovasc Interv. (2020) 96:E496500. doi: $10.1002 / \mathrm{ccd} .28863$

76. Cortese B, Testa L, Di Palma G, Heang TM, Bossi I, Nuruddin AA, et al. Clinical performance of a novel sirolimus-coated balloon in coronary artery disease: EASTBOURNE registry. J Cardiovasc Med (Hagerstown). (2021) 22:94-100. doi: 10.2459/JCM.0000000000001070

Conflict of Interest: The authors declare that the research was conducted in the absence of any commercial or financial relationships that could be construed as a potential conflict of interest.

Publisher's Note: All claims expressed in this article are solely those of the authors and do not necessarily represent those of their affiliated organizations, or those of the publisher, the editors and the reviewers. Any product that may be evaluated in this article, or claim that may be made by its manufacturer, is not guaranteed or endorsed by the publisher.

Copyright (c) 2021 Zhang, Zhang, Dong, Chen, Xu and Jiang. This is an open-access article distributed under the terms of the Creative Commons Attribution License (CC $B Y)$. The use, distribution or reproduction in other forums is permitted, provided the original author(s) and the copyright owner(s) are credited and that the original publication in this journal is cited, in accordance with accepted academic practice. No use, distribution or reproduction is permitted which does not comply with these terms. 